\title{
BRADYCARDIA IN ATHLETES: DOES THE TYPE OF SPORT MAKE ANY DIFFERENCE? - A SYSTEMATIC REVIEW
}

BRADICARDIA EM ATLETAS: A MODALIDADE ESPORTIVA IMPORTA? - UMA REVISÃO SISTEMÁTICA

BRADICARDIA EN ATLETAS: ¿LA MODALIDAD DEPORTIVA IMPORTA? - UNA REVISIÓN SISTEMÁTICA
Systematic ReVIEW ARTICle

ARTIGO DE REVISÃo SISTEMÁTICA Artículo de REVISIÓN SISTEMÁtICA
Michelle Teles Morlin' (D) (Physical Therapist)

Carlos Janssen Gomes da Cruz' (iD (Physical Education Professional) Paula Beatriz Silvestre Melo' (DD (Physical Education Professional) Guilherme Henrique Ramos Lopes' (ID) (Physical Education Professional)

Edgar de Melo Keene Von Koening (1D Soares ${ }^{1}$

(Physical Education Professional) Luiz Guilherme Grossi Porto' (iD (Physical Education Professional) Guilherme Eckhardt Molina' (D) (Physical Education Professional)

1. University of Brasília; Faculty of Physical Education; Exercise Physiology Laboratory, Brasília, DF, Brazil.

\section{Correspondence:}

Michelle Teles Morlin

Exercise Physiology Laboratory.

University of Brasília, Faculty of

Physical Education. Brasília, DF,

Brazil. 70910-900

michelle.morlin@hotmail.com

\begin{abstract}
Bradycardia in athletes can range from moderate to severe, and the factors that contribute to slow heart rate are complex. Studies investigating the mechanisms associated with this condition are controversial, and may be linked to the form of exercise practiced. A systematic literature review was conducted to discuss bradycardia mechanisms in athletes who practice different forms of sport. The databases consulted were Pubmed (MEDLINE), Clinical Trials, Cochrane, Scopus, Web of Science, SciELO, Sport Discus and PEDro. The search included English language articles published up to January 2019, that evaluated athletes who practiced different forms of sport. One hundred and ninety-three articles were found, ten of which met the inclusion criteria, with 1549 male and female athletes who practiced diverse forms of sport. Resting heart rate and cardiac structure were studied in association with the form of sport practiced, through heart rate variability, electrocardiogram, echocardiogram and pharmacological blockade. The studies suggest that a slow resting heart rate cannot be explained by increased vagal modulation alone, but also includes changes in cardiac structure. According to the studies, different sports seem to produce different cardiac responses, and the bradycardia found in athletes can be explained by non-autonomic and autonomic mechanisms, depending on the type of effort or the form of sport practiced. However, the mechanism underlying the slow heart rate in each form of sport is still unclear. Level of evidence ll; Prognostic studies - Investigating the effect of a patient characteristic on the outcome of disease.
\end{abstract}

Keywords: Sports; Athletes; Bradycardia; Cardiovascular physiology; Autonomic nervous system.

\section{RESUMO}

A bradicardia em atletas pode variar de moderada a grave, e os fatores que contribuem para a redução da frequência cardiaca são complexos. Estudos que investigam os mecanismos associados à bradicardia são controversos e, possivelmente, ligados ao tipo de exercício. Realizou-se uma pesquisa bibliográfica sistemática para discutir os mecanismos de bradicardia em atletas de diferentes modalidades esportivas. As bases de dados consultadas foram Pubmed (MEDLINE), Clinical Trials, Cochrane, Scopus, Web of Science, SciELO, Sport Discus e PEDro. Foram incluidos artigos em inglês, que avaliaram atletas de diferentes modalidades esportivas, publicados atéjaneiro de 2019. Cento e noventa e três artigos foram encontrados e dez preencheram os critérios de inclusão, perfazendo 1.549 homens e mulheres atletas de diversas modalidades esportivas. A frequência cardiaca em repouso e a estrutura cardíaca foram estudadas em associação com a modalidade esportiva, porvariabilidade da frequência cardíaca, eletrocardiograma, ecocardiograma e bloqueio farmacológico. Os estudos sugerem que a redução da frequência cardíaca em repouso não é explicada apenas pelo aumento da modulação vagal, mas também por alterações da estrutura cardíaca. De acordo com os estudos, diferentes esportes parecem produzir diferentes respostas cardiacas e a bradicardia encontrada em atletas pode ser explicada por mecanismos não autonômicos e autonômicos. Este achado parece depender do tipo de esforço ou modalidade esportiva praticada. No entanto, o mecanismo envolvido na redução da frequência cardíaca em cada modalidade esportiva ainda não está claro. Nível de evidência Il; Estudos prognósticos - Investigação do efeito de característica de um paciente sobre o desfecho da doença.

Descritores: Esportes; Atletas; Bradicardia; Fisiologia cardiovascular; Sistema nervoso autônomo.

\section{RESUMEN}

La bradicardia en atletas puede variar de moderada a grave, y los factores que contribuyen para la reducción de la frecuencia cardíaca son complejos. Los estudios que investigan los mecanismos asociados a la bradicardia son controvertidos y, posiblemente, vinculados al tipo de ejercicio. Se realizó una investigación bibliográfica sistemática para discutir los mecanismos de bradicardia en atletas de diferentes modalidades deportivas. Las bases de datos consultadas fueron Pubmed (MEDLINE), Clinical Trials, Cochrane, Scopus, Web of Science, SciELO, Sport Discus y PEDro. Se incluyeron artículos en inglés, que evaluaron a atletas de diferentes modalidades deportivas, publicados hasta enero de 2019. Se encontraron ciento noventa y tres artículos y diez cumplieron con los criterios de inclusión, totalizando 1549 hombres y mujeres atletas de diversas modalidades deportivas. La frecuencia cardíaca en reposo y la estructura cardíaca fueron estudiadas en asociación con la modalidad deportiva, por variabilidad de la frecuencia cardíaca, electrocardiograma, ecocardiograma y bloqueo farmacológico. Los estudios sugieren que la reducción de la frecuencia cardíaca en reposo no es explicada sólo por el aumento de la modulación vagal, sino también por alteraciones de la estructura cardíaca. De acuerdo con los estudios, los diferentes deportes parecen producir diferentes 
respuestas cardiacas y la bradicardia encontrada en atletas puede explicarse por mecanismos no autonómicos y autonómicos. Este hallazgo parece depender del tipo de esfuerzo o modalidad deportiva practicada. Sin embargo, el mecanismo involucrado en la reducción de la frecuencia cardíaca en cada modalidad deportiva aún no está claro.

Nivel de evidencia Il; Estudios pronósticos - investigación del efecto de característica de un paciente sobre el desenlace de la enfermedad.

Descriptores: Deportes; Atletas; Bradicardia; Fisiología cardiovascular; Sistema nervioso autónomo.

\section{INTRODUCTION}

In the field of sports, athletes commonly have a resting heart rate below 60 bpm, a chronic adaptation known as athlete's bradycardia. Functionally, bradycardia induced by physical training increases ventricular filling time and, consequently, contributes to increase systolic volume in resting and physical exercise conditions. ${ }^{1}$ However, despite an assumed consensus in the literature as to the athlete's bradycardic phenomenon induced by physical training, as well as its functionalities, the mechanisms responsible for such adaptation are still current targets of debate.

In this respect, it has been elegantly demonstrated through pharmacological blockade that athlete bradycardia can be the result of a change in cardiac autonomic balance. Specifically, these studies suggest that increased parasympathetic activity and reduced sympathetic activity of the heart are responsible for the reduction in the frequency of sinus node shots. ${ }^{2-6}$ On the other hand, the autonomic hypothesis has been refuted in some other studies, suggesting that the main adaptation responsible for athlete's bradycardia is the intrinsic reduction of the sinus node firing frequency. ${ }^{7-10}$

Despite that, since different training models and professions may result in different forms of cardiovascular overload, and considering that physiological chronic adaptations induced by physical training are specific to the type of stimuli offered during successive training sessions, ${ }^{11-13}$ it is plausible to hypothesize that the mechanisms responsible for bradycardia are dependent on the athletic modality. In fact, functional and structural differences have been reported in hearts of athletes involved in different athletic modalities. ${ }^{14}$

Therefore, given the controversy about the mechanisms primarily responsible for athlete's bradycardia and the possibility of such divergences being driven by the athletic modality, the objective of the present study is to conduct a systematic review of studies that have investigated the mechanisms responsible for bradycardia in athletes involved in different athletic modalities. To the best of our knowledge, this is the first study to carry out a review and critical analysis of the literature on the subject.

\section{METHODS}

The PRISMA guidelines (Preferred Reporting Items for Systematic Reviews and Meta-Analyzes) were adopted in the systematic review process. ${ }^{15}$ Two reviewers (MM, LG) conducted the search independently and a senior reviewer (MG) was to be invited to resolve any divergence, which was not necessary. The agreement analysis between the two independent reviewers was evaluated using the Kappa index with a 95\% confidence interval.

We searched in the following databases: Pubmed (MEDLINE), Clinical Trials, Scopus, Web of Science, SciELO (Scientific Electronic Library), Sport Discus and PEDro, up to January 2019, in view of the time needed for data extraction, analysis of results and writing of the manuscript. The Cochrane database was consulted to verify the existence of revisions about this topic.

The following keywords were used for the searches: "sports AND nervous system; parasympathetic AND sympathetic"; "sports AND bradycardia"; "athletes AND nervous system AND parasympathetic AND sympathetic";"athletes AND bradycardia"; "exercise AND nervous system AND parasympathetic AND sympathetic";"exercise AND bradycardia". The descriptors used were extracted from the PUBMED (Medical Subjects Headings- MeSH) and DeCS (Health Sciences Descriptors) databases.

References were added to a reference manager for collection and subsequent analysis of titles and abstracts. After careful reading of the articles, studies published in English that directly or indirectly evaluated the possible mechanisms associated with sinus bradycardia of athletes involved in different sports modalities were included in the review. Consequently, we did not include studies in a language other than English, nor studies with children, adolescents or master athletes; animals; or evaluating only non-athletes or sedentary individuals without comparison to athletes; with unhealthy subjects or that did not specify the sport modality practiced by the volunteers. Information about age, sport modality, form of bradycardia evaluation and proposed mechanisms for bradycardia were extracted from the articles and organized as a table.

\section{RESULTS}

The concordance analysis among the reviewers showed a Kappa value of 0.85 , which indicates almost perfect agreement. We found 193 articles in the databases referred above. Of these, 155 were excluded based on their title and abstract and 10 papers were duplicate articles. Of the 28 remaining manuscripts, two were in a language other than English, nine were crosstalk, viewpoints or conference papers, two did not specify the sport evaluated and five evaluated adolescents or children. However, these, although excluded from the main analysis, provided subsidies for a better discussion of the articles. Thus, 10 articles were selected for this review, based on the inclusion criteria. Figure 1 describes the article selection process.

The total sample consisted of 1549 athletes aged 17-36 years, who practiced different athletic modalities such as a) cycling (71 athletes or $4.6 \%)$, b) running (13 athletes or $0.8 \%), c)$ ball sports and martial arts (1036 athletes or 66.9\%), d) gymnastics (111 athletes or $7.2 \%)$, and e) resistance sports (318 athletes or 20.5\%).

Three studies compared athletes of different athletic modalities. ${ }^{16-18}$ Most of the studies evaluated men (8 studies) and two did not specify the sex of the individuals evaluated. 16,19 Two studies evaluated women; however, none of them reported menstrual cycle phase control, which may influence heart rate variability and resting heart rate itself. 18,20

The studies used pharmacological blockade, ${ }^{17,21}$ electrocardiogram, ${ }^{2,10,16-19,21,22}$ echocardiogram, ${ }^{16,17,21-23}$ and heart rate variability 2,10,20,23 to evaluate mechanisms that could explain heart rate reduction after an exercise training period. The descriptive analysis of the articles is summarized in Tables 1 and 2 and they are organized in order of the year of publication.

\section{DISCUSSION}

The main findings of this study are that the effect of physical training on athletes' heart rhythm, in resting condition, does not strongly suggest 


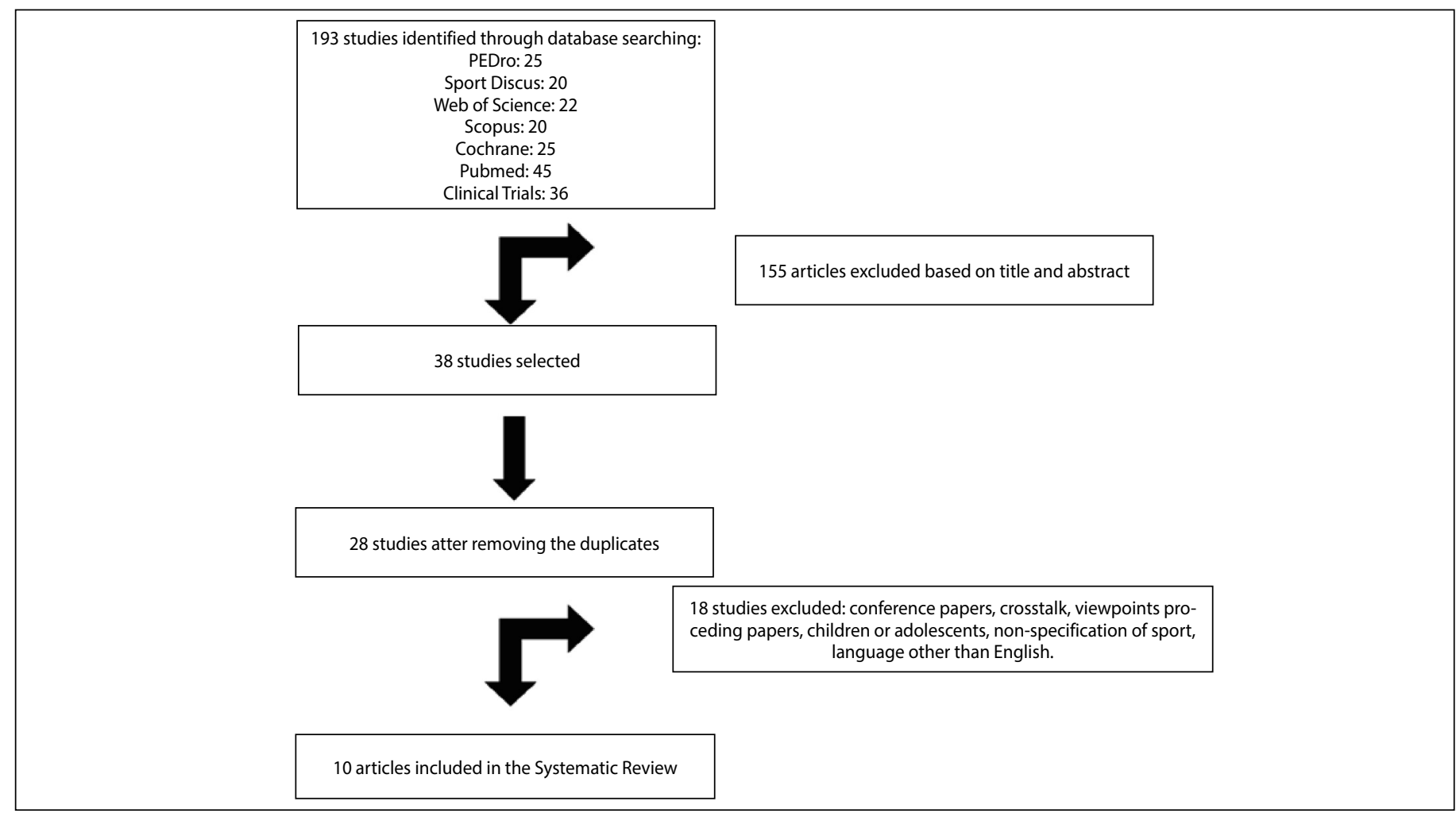

Figure 1. Research and selection of articles.

Table 1. Descriptive results.

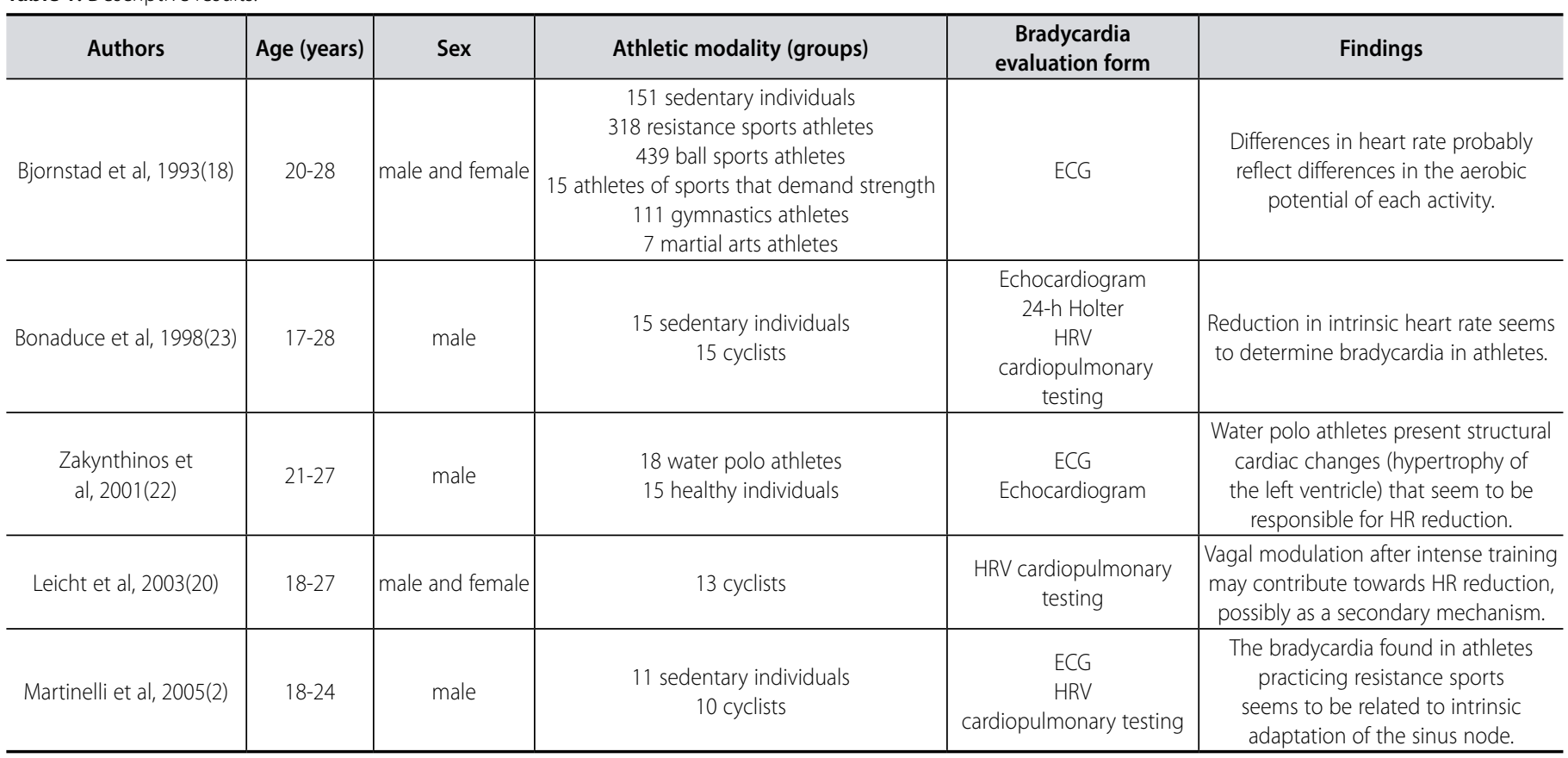

the possible influence of the type of athletic modality as an intervening variable in training-related bradycardia, autonomic or non-autonomic. On the other hand, only two recently published studies ${ }^{17,19}$ showed that athletic modality (running, cycling and wrestlers) may possibly influence the type of adaptation that occurs in the physiological mechanisms of cardiac control in athletes in resting condition.

This review shows that six (60\%) articles selected evaluated cyclists (71 cyclists) and observed that bradycardia may be explained by non-autonomic mechanisms. Four of these studies 2,10,20,23 evaluated bradycardia and its possible mechanisms through the heart rate variability method at rest. These studies suggest that heart rate reduction is not entirely dependent on autonomic control or specifically on increased vagal activity at rest. Molina et al. ${ }^{10}$ compared a group of professional cyclists with a group of non-athlete physically trained individuals. Although the group of cyclists presented bradycardia in resting condition, compared to the group of physically trained individuals, the authors did not see a difference in cardiac autonomic control from heart rate variability in the supine and orthostatic positions, as well as after active postural change (orthostatic test). The authors suggest that the bradycardia observed in cyclists seems to be related to an altered intrinsic heart rate. ${ }^{10}$ It is important to note that heart rate variability measures vagal modulation and not vagal tone, and may directly influence resting heart rate.

In this regard, the study by Leicht et al. ${ }^{20}$ observes that vagal modulation after intense training may be a secondary mechanism to reduce heart rate. 
Table 2. Descriptive results (continued).

\begin{tabular}{|c|c|c|c|c|c|}
\hline Authors & Age (years) & Sex & $\begin{array}{l}\text { Athletic modality } \\
\text { (Groups) }\end{array}$ & $\begin{array}{c}\text { Bradycardia } \\
\text { Evaluation form }\end{array}$ & Findings \\
\hline $\begin{array}{l}\text { belotserkovskiiet } \\
\text { al, 2009(16) }\end{array}$ & $17-29$ & unspecified & $\begin{array}{l}527 \text { basketball, water } \\
\text { polo, boxing and } \\
\text { soccer athletes }\end{array}$ & $\begin{array}{l}\text { ECG } \\
\text { Polycardiography } \\
\text { Echocardiogram }\end{array}$ & $\begin{array}{l}\text { Sport activity alters the functional and } \\
\text { morphological cardiovascular characteristics. } \\
\text { Thus, athletes present complex characteristics } \\
\text { to maintain cardiovascular function. }\end{array}$ \\
\hline Kaur, 2013(19) & $18-24$ & unspecified & $\begin{array}{l}30 \text { wrestlers athletes } \\
30 \text { healthy individuals }\end{array}$ & $\begin{array}{c}\text { ECG } \\
\text { Echocardiogram } \\
\end{array}$ & $\begin{array}{l}\text { Resistance-predominant sports result in changes in } \\
\text { cardiac dimensions (left ventricle concentric hypertrophy) }\end{array}$ \\
\hline Molina et al, 2013(10) & $22-31$ & male & $\begin{array}{l}12 \text { cyclists } \\
11 \text { healthy individuals }\end{array}$ & $\begin{array}{c}\text { ECG } \\
\text { HRV } \\
\text { cardiopulmonary testing } \\
\end{array}$ & $\begin{array}{l}\text { Bradycardia is not dependent on autonomic } \\
\text { modulation, rather, it suggests intrinsic changes. }\end{array}$ \\
\hline Azevedo et al, 2014(17) & $22-36$ & male & $\begin{array}{l}13 \text { runners } \\
11 \text { cyclists }\end{array}$ & $\begin{array}{c}\text { ECG } \\
\text { Pharmacological blockade } \\
\text { Echocardiogram }\end{array}$ & $\begin{array}{l}\text { Bradycardia observed in cyclists seems to be } \\
\text { associated with reduction on sinus node frequency } \\
\text { and structural cardiac changes (septal and posterior } \\
\text { wall). On the oder hand, bradycardia observed in } \\
\text { runners are related to higher parasympathetic. }\end{array}$ \\
\hline Azevedo et al, 2016(21) & $25-27$ & male & 10 cyclists & $\begin{array}{c}\text { ECG } \\
\text { Pharmacological blockade } \\
\text { Echocardiogram }\end{array}$ & $\begin{array}{l}\text { Bradycardia can be explained by autonomic and non- } \\
\text { autonomic mechanisms according to the training phase }\end{array}$ \\
\hline
\end{tabular}

In addition, Martinelli et al. ${ }^{2}$ argues that bradycardia in cyclists may be related to intrinsic adaptations of the sinus node. This finding was also observed by Bonaduce et al. ${ }^{23}$ who concludes that intrinsic heart rate reduction seems to determine bradycardia in cyclist athletes. In this regard, two papers raise the hypothesis of a possible relation between sport modality and bradycardia mechanism, evaluating athletes at rest and post-exertion. 10,24 Interestingly, these studies used heart rate variability for evaluation.

To try to explain the possible physiological mechanisms involved in the bradycardia of athletes practicing different athletic modalities, Azevedo et al. ${ }^{17}$ compared cyclers and runners, using double pharmacological blockade and echocardiography. They concluded that the magnitude of bradycardia observed in cyclists could be explained by intrinsic heart rate reduction, possibly associated with concentric and eccentric hypertrophy observed in the walls of the heart. This hypothesis is supported by studies such as the one by Lewis et al., ${ }_{1}^{14}$ who observe intrinsic heart rate reduction in cyclists and speculate that dilation of the cardiac chamber would cause a stretch of the sinoatrial node, leading to its inhibition as an acute response. Still in this regard, the study by Azevedo et al. ${ }^{17}$ showed that the athletic modality (running or cycling) could determine the magnitude of the vagal effect and the intrinsic heart rate. The article suggests that vagal modulation could coexist with changes in the sinus node in highly trained runners and the opposite could be applied to professional cyclists.

In studies evaluating cardiac structure, there is a concern with the type of the training and dimensions of the heart. Research using the echocardiogram method ${ }^{25-29}$ to investigate the effects of physical training on the heart, ventricular wall and mass dimensions in athletes who practiced diverse sports demonstrated that athletes who engage in sports with greater overload to heart resistance such as, for example, exercise that consists of predominantly isometric work (e.g. weight lifting) develop concentric hypertrophy in the heart. In contrast, athletes who perform sports with greater volume overload, such as isotonic exercises (e.g. marathon runners), develop an increase of all cardiac chambers. ${ }^{16}$ Therefore, it is plausible to conjecture that the type training overload (volume and / or resistance) and the position in which the athlete usually trains are variables that may influence the type of cardiac adaptation, that is, different autonomic or non-autonomic adaptations may result from different training overloads and training phases. The study by Kaur ${ }^{19}$ further states that training involving mostly strength results in changes in cardiac dimensions. This study reveals a significant increase of the interventricular and posterior septal walls in wrestlers athletes.

Still on cardiac structure, Zakynthinos et al. ${ }^{22}$ found that athletes who practiced water polo had dilatation of the cardiac chambers, combined with hypertrophy, but preservation of normal left ventricular function. Belotserkovskii et al. ${ }^{16}$ suggest that athletic activity has a distinct effect on the morphology and function of the cardiovascular system.

In the studies by Miki, Nishimura and Urhausen, ${ }^{30-32}$ evaluating athletic modalities with exercises causing both volume and resistance overload, both left ventricular dilation and hypertrophy were observed. However, no association analysis was performed with cardiac rhythm or bradycardia mechanism. This could be pointed out as a possible limitation of studies for the evaluation of cardiac adaptations to exercise.

The findings of this research suggest that the bradycardia found in athletes can be explained by non-autonomic and autonomic mechanisms, depending on the type of effort or athletic modality. Still in this regard, another factor that could influence cardiac adaptation is the training phase. The recent study by Azevedo et al., ${ }^{21}$ published in 2016, when evaluating professional cyclists, showed differences between the transitional and the competitive phases of training, in addition to their influence on resting heart rate. Thus, there is evidence that, in addition to athletic modality, the training phase may modify the magnitude of heart rate control mechanisms, even if temporarily.

\section{CONCLUSION}

Studies show that bradycardia may be related to not only athletic modality but also type of training. The findings of the present study suggest that athletic modality and type of training produce different cardiac adaptations that result in structural alterations of diverse magnitudes, which can influence the sinusal rhythm.

The mechanisms involved in each athletic modality are still inconclusive and, although there is some research on the mechanisms of bradycardia, this review reinforces the need for other studies on the subject. Our findings suggest that new studies addressed to better understand the mechanism of athlete's bradycardia should compose more homogenic groups of volunteers, in terms of the sport modality, type and phase of exercise training. In other words, it seems that the comparison of athletes vs non-athletes it is a comprehensive approach.

The understanding of the possible mechanisms and their relationship with the athletic modality or the type of training can help health professionals to understand the phenomenon and its relationship with sports, mainly in the evaluation and monitoring of professional athletes.

All authors declare no potential conflict of interest related to this article 
AUTHORS' CONTRIBUTIONS: Each author made significant individual contributions to this manuscript. MTM and GHRL: data acquisition, data analysis and interpretation; PBM: substantial contribution to the concept and design; CJGC, EMKVKS and LGGP: critical review of the article and intellectual contributions; GEM: analysis and interpretation of data, critical review of the manuscript. All authors approved the final version of the manuscript.

\section{REFERENCES}

1. Boyett MR, D'Souza A, Zhang H, Morris GM, Dobrzynski H, Monfredi O. Viewpoint: is the resting bradycardia in athletes the result of remodeling of the sinoatrial node rather than high vagal tone? J Appl Physiol (1985). 2013;114(9):1351-5.

2. Martinelli FS, Chacon-Mikahil MP, Martins LE, Lima-Filho EC, Golfetti R, Paschoal MA, et al. Heart rate variability in athletes and nonathletes at rest and during head-up tilt. Braz J Med Biol Res. 2005;38(4):639-47.

3. Chapman JH. Profound sinus bradycardia in the athletic heart syndrome. J Sports Med Phys Fitness. 1982;22(1):45-8.

4. Dixon EM, Kamath MV, McCartney N, Fallen EL. Neural regulation of heart rate variability in endurance athletes and sedentary controls. Cardiovasc Res. 1992;26(7):713-9.

5. Uusitalo AL, Tahvanainen KU, Uusitalo AJ, Rusko HK. Non-invasive evaluation of sympathovagal balance in athletes by time and frequency domain analyses of heart rate and blood pressure variability. Clin Physiol Oxf Engl. 1996;16(6):575-88

6. Shin K, Minamitani H, Onishi S, Yamazaki H, Lee M. Autonomic differences between athletes and nonathletes: spectral analysis approach. Med Sci Sports Exerc. 1997;29(11):1482-90.

7. Aubert AE, Seps B, Beckers F. Heart rate variability in athletes. Sports Med. 2003;33(12):889-919.

8. Stein R, Medeiros CM, Rosito GA, Zimerman LI, Ribeiro JP. Intrinsic sinus and atrioventricular node electrophysiologic adaptations in endurance athletes. J Am Coll Cardiol. 2002;39(6):1033-8.

9. Stein R, Moraes RS, Cavalcanti AV, Ferlin EL, Zimerman LI, Ribeiro JP. Atrial automaticity and atrioventricular conduction in athletes: contribution of autonomic regulation. Eur J Appl Physiol. 2000;82(1-2):155-7.

10. Molina GE, Porto LG, Fontana KE, Junqueira Jr LF. Unaltered R-R interval variability and bradycardia in cyclists as compared with non-athletes. Clin Auton Res. 2013;23(3):141-8.

11. Korre M, Sampani K, Porto LG, Farioli A, Yang Y, Christiani DC, et al. Cardiac enlargement in US Firefighters: prevalence estimates by echocardiography, cardiac magnetic resonance and autopsies. J Clin Exp Cardiolog. 2016;7(7):1-6.

12. Pelliccia A, Culasso F, Di Paolo FM, Maron BJ. Physiologic left ventricular cavity dilatation in elite athletes. Ann Intern Med. 1999;130(1):23-31.

13. Fernandes T, Soci UP, Oliveira EM. Eccentric and concentric cardiac hypertrophy induced by exercise training: microRNAs and molecular determinants. Braz J Med Biol Res. 2011;44(9):836-47.

14. Lewis SF, Nylander E, Gad P, Areskog NH. Non-autonomic component in bradycardia of endurance trained men at rest and during exercise. Acta Physiol Scand. 1980;109(3):297-305.

15. Liberati A, Altman DG, Tetzlaff J, Mulrow C, Gøtzsche PC, loannidis JP, et al. The Prisma statement for reporting systematic reviews and meta-analyses of studies that evaluate healthcare interventions: explanation and elaboration. BMJ. 2009;339:b2700.

16. Belotserkovskii ZB, Lyubina BG, Koidinova GA. Cardiac function and physical working capacity of athletes with altered ventricular repolarization. Hum Physiol. 2009;35(1):80-9.
17. Azevedo LF, Perlingeiro PS, Hachul DT, Gomes-Santos IL, Brum PC, Allison TG, et al. Sport modality affects bradycardia level and its mechanisms of control in professional athletes. Int J Sports Med. 2014;35(11):954-9.

18. Bjørnstad H, Storstein L, Dyre Meen H, Hals O. Electrocardiographic findings according to level of fitness and sport activity. Cardiology. 1993;83(4):268-79.

19. Kaur K. Non invasive evaluation of cardiac dimensions in professional wrestlers. Sport Med J. 2013;9(2):2101-5.

20. Leicht AS, Allen GD, Hoey AJ. Influence of intensive cycling training on heart rate variability during rest and exercise. Can J Appl Physiol. 2003;28(6):898-909.

21. Azevedo LF, Perlingeiro P, Hachul DT, Gomes-Santos IL, Tsutsui JM, Negrao CE, et al. Predominance of Intrinsic Mechanism of Resting Heart Rate Control and Preserved Baroreflex Sensitivity in Professional Cyclists after Competitive Training. PloS One. 2016;11(1):e0148036.

22. Zakynthinos E, Vassilakopoulos T, Mavrommati I, Filippatos G, Roussos C, Zakynthinos S. Echocardiographic and ambulatory electrocardiographic findings in elite water-polo athletes. Scand J Med Sci Sports. 2001;11(3):149-55.

23. Bonaduce D, Petretta M, Cavallaro V, Apicella C, lanniciello A, Romano M, et al. Intensive training and cardiac autonomic control in high level athletes. Med Sci Sports Exerc. 1998;30(5):691-6.

24. Yamamoto K, Miyachi M, Saitoh T, Yoshioka A, Onodera S. Effects of endurance training on resting and post-exercise cardiac autonomic control. Med Sci Sports Exerc. 2001;33(9):1496-502.

25. DeMaria AN, Neumann A, Lee G, Fowler W, Mason DT. Alterations in ventricular mass and performance induced by exercise training in man evaluated by echocardiography. Circulation. 1978;57(2):237-44

26. Huonker M, Halle M, Keul J. Structural and functional adaptations of the cardiovascular system by training Int J Sports Med. 1996;17(Suppl 3):S164-72.

27. Longhurst JC, Stebbins CL. The power athlete. Cardiol Clin. 1997;15(3):413-29.

28. Maron BJ. Structural features of the athlete heart as defined by echocardiography. J Am Coll Cardiol. 1986;7(1):190-203.

29. Mills JD, Moore GE, Thompson PD. The athlete's heart. Clin Sports Med. 1997;16(4):725-37.

30. Miki T, Yokota Y, Seo T, Yokoyama M. Echocardiographic findings in 104 professional cyclists with follow-up study. Am Heart J. 1994;127(4 Pt 1):898-905.

31. Nishimura T, Yamada Y, Kawai C. Echocardiographic evaluation of long-term effects of exercise on left ventricular hypertrophy and function in professional bicyclists. Circulation. 1980;61(4):832-40.

32. Urhausen A, MonzT, Kindermann W. Sports-specific adaptation of left ventricular muscle mass in athlete's heart. I. An echocardiographic study with combined isometric and dynamic exercise trained athletes (male and female rowers). Int J Sports Med. 1996;17 (Suppl 3):S145-51. 